\title{
Entomopathogenic Exploration Practicum Test For Mustard Fungi in the Laboratory of Biology Students FKIP- UISU 2019
}

\author{
Edi Azwar \\ Faculty of Teachers Training and Education, North Sumatera Islamic University, Medan, 20217, Indonesia \\ Ediazwar@fkip.uisu.ac.id \\ ${ }^{*}$ Corresponding Author \\ Whatsapp Number [+62-8126346780]
}

How to Cite : Azwar, E. (2019). Entomopathogenic Exploration Practicum Test For Mustard Fungi in the Laboratory of Biology Students FKIP- UISU 2019. International Journal for Educational and Vocational Studies, 1(5), 503-508

\section{ARTICLE HISTORY}

Received: 13 June 2019

Revised: 22 July 2019

Accepted: 24 August 2019

\section{KEYWORDS}

Entomopathogenic;

Exploration;

Practicum Test;

Learning outcome ;

\begin{abstract}
Utilization of entomopathogenic fungi as biological control agents is one way to avoid the negative impact of chemicals on the environment. Entomopathogenic fungi that have been widely used for biological pest control are Beauveria bassiana, Metarhizium anisopliae, Aspergillus sp., Nomuraea rileyi. The purpose of this study was to determine the presence of fungi entomopathogenic in the Brassica chinensis vegetable farm, to find out the entomopathogenic characteristics of fungi obtained from each Brassica chinensis planting soil sample, to know the highest entomopathogenic fungi obtained from the exploration of entomopathogenic fungi and to study the results of biology student learning semester VI in microbiology courses. To obtain the entomopathogenic fungi, an exploration technique was carried out using the insect bait Tenebrio molitor placed in the rhizosphere of the Brassica chinensis plant. The preparation in this study involved taking samples from 5 villages in Berastagi, namely Barus Julu, Persadanta, Rumah Rih, Paribun, and Suka Julu by determining 5 diagonal soil sample points. The results of fungi entomopathogenic exploration from 5 villages in Berastagi, there are 3 genus of entomopathogenic fungi in Brassica chinensis rhizosphere, Metarhizium, Beauveria and Aspergillus. The highest fungi entomopathogenic diversity was obtained by Beauveria fungi with a diversity index of 0.3628 while the lowest diversity was obtained by Aspergillus with a diversity index of 0.0343 overall. The results of learning to students indicate that, the ability of students at the time of the pre-test obtained an average value of 59.26 with a standard deviation of 12.8 while at the post-test students obtained an average value of 73.68 with a standard deviation of 8.3 Based on the acquisition of grades on average there is an increase in student learning outcomes in entomopathogenic fungi submateri.
\end{abstract}

\section{INTRODUCTION}

Increased problems with pests and diseases continue to occur on agricultural land including Brassica chinensis agriculture. Target pests that are usually found in mustard plants are tritip caterpillars (Plutella xylostella), growth point caterpillars (Crocidolomia binotalis), grayak caterpillars (Spodoptera litura) in addition to target pests there are also other pests such as insects (non-target Arthropods). Insects have a very important role in life. Insects can act as a remodel of organic matter into minerals needed by plants, insects also play a role in helping pollinate plants. Besides being beneficial, insects can also cause harm including being a pest to plants and can also be a vector that causes disease in animals and humans. The existence of these pests and diseases if not- controlled can cause significant damage to plants resulting in a lack of plant productivity. This will certainly cause losses to farmers, both in quality and quantity. This factor is one of the reasons for continuing to carry out integrated pest and disease control. So far, pest control using synthetic pesticides is still the main control technique, but it is known that the use of synthetic pesticides has a negative impact on humans, animals and the environment. Along with increasing public awareness of the importance of health and the dangers of pesticides, organic pesticide-free vegetables are an important alternative to creating healthy communities through consumption of vegetables and fruit.

Berastagi, as a gateway to the export of vegetables and fruit in North Sumatra, has the potential to become an 
organic vegetable production center, with an area of 25.96 ha, currently being promoted by the cultivation of organic vegetables both by research institutions and the local community.

The challenge faced by the perpetrators of organic vegetable cultivation is the increase in pests and agricultural land that has been using synthetic fertilizers. The use of synthetic insecticides does not actually eradicate pests but will lead to new problems such as the killing of natural predators (natural enemies), pest resistance, pest resurgence (events increasing the target pest population is higher than the previous population level), the emergence of environmental pollution, the emergence of hazards to humans and the rejection of hazards to humans agricultural products due to pesticide residues that exceed the tolerance threshold by consumers. Based on the above facts, there is really no reason for us not to try to develop alternative ways of controlling pests that are safe but still support the achievement of maximum crop production. Alternative pest control is carried out by agents of biological control of plant pests (the use of natural enemies). The natural enemy used comes from entomopathogenic fungi found in insects. Utilization of entomopathogenic fungi as biological control agents is one way to avoid the negative impact of chemicals on the environment. Biological control will not damage the environment and not kill non-target organisms, biological control is part of natural control. Biological control utilizes controlling factors that already exist in nature, namely natural enemies of the controlled organisms.

These natural enemies include parasitoids, predators and pathogens (nematodes, bacteria, viruses and fungi). The results of fungi entomopathogenic exploratory research can be used as teaching material for biology students in semester VI of microbiology courses. The process of learning biology can be directed to activities that encourage students to actively learn physically, socially, and psychologically in understanding the material. The aim of teaching biology is that students can apply biology knowledge in daily life. One branch of biology is Microbiology. Microbiology is an extension and deepening of Biology and learns about all microscopic creatures in the form of single cells, multicellular or acellular. Microbiology course is one of the courses in the biology education program at the Faculty of Mathematics and Natural Sciences UISU.

\section{METHODS}

\subsection{Research Location, Materials and Tools}

\subsubsection{Research Location}

This research was conducted in 5 Brassica chinensis Berastagi vegetable farms, namely Paribun village, Barus Julu village, Persadanta village, Suka Julu village, Rumah Rih village and Biology Laboratory FKIP UISU Medan.
The time of the research is April to June 2019.

\subsubsection{Materials and Tools}

\subsubsection{Materials}

a) Hoe: 1 piece

b) Plastic bags: 20 pieces

c) Label paper: as necessary

d) Filter soil: 1 piece

e) Plastic containers: 10 pieces

f) Microscope: 1 piece

g) Cover glass: 2 pieces

h) Glass objects: 2 pieces

i) Gauze. : 1 box

j) Camera documentation: 1 piece

k) Tissu: 1 box

\subsubsection{Tools}

a) Sampled rooting of Brassica chinensis: To taste

b) Hongkong caterpillar larvae (Tenebrio molitor) third instar: 100 tails

c) Sterile aquades: $1 \mathrm{~L}$

\subsection{Population and Sample}

\subsubsection{Population}

Population is the total number of subjects to be studied. The population in this study were all agricultural land of Brassica chinensis centers located in Berastagi.

\subsubsection{Sample}

The sample is a part of the population that represents the overall population characteristics. So the samples in this study were soil samples from the Brassica chinensis rhizosphere plant taken from 5 villages in Berastagi which were then given larvae of Tenebrio molitor.

\subsection{Research Design, Work Procedure,and Observation}

\subsubsection{Research Design}

In this study the method used is an exploration method. Where the Brassica chinensis rhizosphere soil samples were obtained from 5 villages in Berastagi. Exploring fungi in the ground around the roots of plants with a depth of 5 to $15 \mathrm{~cm}$. Soil samples are taken according to the sampling determination. The soil is then put into plastic and mixed until it is homogeneous. The soil sample obtained is placed in a plastic container, filled in approximately half of the volume of the container. Then the soil is moistened with sufficient sterile water. Placing Tenebrio molitor caterpillars on the surface of the soil in a container, the caterpillars that are inserted are newly molting caterpillars (changing skin) that are white. Furthermore, the container is closed using gauze so that the caterpillar does not come 
out of the container. Then incubated for 1 to 2 weeks in a dark place so that the caterpillar traps move actively, so that it is easy to contact with the entomopathogenic fungi that are in the soil. The design of research in learning biology. The research design can be illustrated that prior to the learning process in semester VI with Microbiology courses to determine the initial ability is given pre-test (IT). After that, it is treated with the lecture method (Y), and given the final ability of the material taught by Post test (T2).

\section{3.2 Work Procedure}

1. In the Berastagi Brassica chinensis Vegetable Farm

Retrieval Stage Brassica chinensis rhizosphere soil

Rhizosphere soil uptake is done by separating the roots of the Brassica chinensis plant from the soil at five points. Soil sampling must be 5 to $15 \mathrm{~cm}$ deep. The soil sample is then put into a plastic bag and mixed until homogeneously into 2 soil samples and then bound. The soil is labeled regarding the location of collection and time of soil sampling. After the soil sampling is completed from 5 villages in Brastagi, then proceed to filter the soil sample using a soil filter so that the soil texture becomes smooth. The fine soil sample is then put into a plastic container filled about half of the volume of the container in accordance with the location of the sample that has been printed on the plastic container.

\section{In the Biology Laboratory FKIP UISU}

\section{a. Application stage}

1) Prepare 100 third instar Tenebrio molitor larvae.

2) Place 10 larvae of the third instar Tenebrio molitor larvae on the surface of the soil sample in each container, then the soil that contains the larvae is sprayed with sterile aquades until the soil becomes moist.

3) Cover the plastic container so that the Tenebrio molitor larvae do not come out. For further research soil samples containing larvae of Tenebrio molitor below to the Laboratory.

4) Soil samples are then removed and replaced with gauze so that the air in the ground can be swapped. And don't let dry soil samples try to keep the soil moist, so the fungus can grow and be stored in a dark place to accelerate the growth of fungi.

\subsubsection{Observations}

Observations made after the application process is complete, observations carried out for two weeks. Where for the past two weeks soil samples containing larvae of Tenebrio molitor remained observed for two days in 2 weeks. The larvae attacked by fungi will eventually die and will form entomopathogenic fungi on the body part of the larvae of Tenebrio molitor.

\section{Identification of entomopathogenic function}

The acquired fungi are identified up to the genus level by observing macroscopically (color, shape and direction of colony growth) and microscopically (branching conidiophores and the form of conidia fungi)

\section{Entomopathogenic fungi diversity}

Data from fungi entomopathogenic research results obtained from 5 villages in Berastagi then calculated values: absolute density, relative density, absolute frequency, relative frequency, importance value index and species diversity index using the Shannon-winner $(\mathrm{H})$ formula in Nurudin (2013: 3) namely:

\section{Absolute Density}

Number of entomopathogenic infected larvae in each village sample

\section{Relative Density (KR)}

$\mathrm{KR}=$ (Number of larvae infected with entomopathogenic fungi)/(Total number of larvae infected with entomopathogenic fungi) x 100\%

\section{Absolute Frequency}

Number of village samples whose larvae were infected by entomopathogenic fungi

\section{Relative Frequency (FR)}

$\mathrm{FR}=$ (Number of samples of villages infected with entomopathogenic fungi)/(Total number of samples of villages infected with entomopathogenic fungi) x 100\%

\section{Importance Value Index (INP)}

$\mathrm{INP}=\mathrm{KR}+\mathrm{FR}$ Shannon-Winner Type Diversity $\left(\mathrm{H}=\mathrm{Pi}^{2}\right.$ Ln $\mathrm{P}$ or $\mathrm{H}=\mathrm{Pi}^{2} \log \mathrm{Pi}$

Where:

$\mathrm{H}=$ index of species diversity

$\mathrm{Pi}=\mathrm{Ni} / \mathrm{N}=$ Number of individuals of a species / total number of all species

$\mathrm{Ni}=$ Number of individuals of type 1

$\mathrm{N}=$ Number of individuals of all types

$\mathrm{Ln}=$ natural logarithm

With criteria:

$\mathrm{H}<1=$ Low diversity.

$1<\mathrm{H}<3=$ Medium diversity.

$\mathrm{H}>3=$ High diversity

\subsubsection{Pree Test}

Pre test is a test conducted at the beginning of learning of the material taught before the teaching and learning process takes place which aims to find out the basic abilities of students to entomopathogenic submateries with a total of 5 questions (items) and questions in the form of essays.

\subsubsection{Post Test}

Post test is a test conducted at the end of learning about the material that has been studied which aims to determine student learning outcomes after studying the entomopathogenic function of the fungus. The test in this study is in the form of essays with a total of 10 questions. 


\section{RESULTS AND DISCUSSION}

\section{Results}

Based on the table above it can be seen that the highest average value of white fungal infection is 2.5 larvae from the sample of Persadanta village and Rumah Rih village, while the highest average value of green fungal infection is2 larvae from the sample of Rumah Rih village and the average value the highest mean yellow fungal infection was 1 larva from the sample village Persadanta. From the results of exploration conducted using Tenebrio molitor insect bait, there were 3 types of white fungi (Figure 11) which were suspected as Beauveria (white muscardine), green fungi (Figure 10) which were suspected as Metarhizium (green muscardine) and yellow fungi (Figure 12) suspected as Aspergillus.

Table 1. Molitor Larvae attacked by entomopathogenic fungi in the Brastagi Vegetable farm from 5 villages with 2 replications:

\begin{tabular}{|c|c|c|c|c|c|c|c|c|c|c|}
\hline \multirow[t]{2}{*}{ No } & \multirow[t]{2}{*}{$\begin{array}{l}\text { Source of Soil } \\
\text { Sample }\end{array}$} & \multicolumn{2}{|c|}{$\begin{array}{c}\text { Number of Larvae } \\
\text { Infected with Beauveria } \\
\text { fungi on Repetition } \\
\text { Number }\end{array}$} & \multicolumn{2}{|c|}{$\begin{array}{l}\text { Number of Larvae } \\
\text { Infected with } \\
\text { Metarhizium fungi on } \\
\text { Repetition Number }\end{array}$} & \multicolumn{2}{|c|}{$\begin{array}{c}\text { Number of Larvae } \\
\text { Infected with Aspergillus } \\
\text { fungi on Repetition } \\
\text { Number }\end{array}$} & \multicolumn{3}{|c|}{ Average of Fungi Infection } \\
\hline & & 1 & 2 & 1 & 2 & 1 & 2 & $\mathrm{FP}$ & $\mathrm{FH}$ & FK \\
\hline 1 & Paribun village & 3 & 0 & 2 & 1 & 0 & 0 & 1,5 & 1,5 & 0 \\
\hline 2 & Barus julu village & 2 & 1 & 0 & 1 & 0 & 0 & 1.5 & 0,5 & 0 \\
\hline 3 & Persadanta village & 1 & 4 & 1 & 2 & 1 & 1 & 2,5 & 1,5 & 1 \\
\hline 4 & Suka julu village & 1 & 3 & 1 & 1 & 0 & 0 & 2 & 1 & 0 \\
\hline 5 & Rumah Rih village & 3 & 2 & 3 & 1 & 0 & 1 & 2,5 & 2 & 0,5 \\
\hline
\end{tabular}

Information: FP: White fungi (Beauveria)

FH: Green fungi (Metarhizium)

FK: Fungi are yellow (Aspergillus)

Table 2. Entomopathogenic Fungi Diversity

\begin{tabular}{|c|c|c|c|c|c|c|c|}
\hline No & Genus & $\mathrm{KM}$ & $\mathrm{FM}$ & $\begin{array}{c}\mathrm{KR} \\
\%\end{array}$ & $\frac{\mathrm{FR}}{\%}$ & $\begin{array}{c}\text { INP } \\
\%\end{array}$ & $\mathrm{H}$ \\
\hline 1 & Beauveria & 20 & 9 & 55,56 & 42,86 & 98,42 & 0,3628 \\
\hline 2 & Metarhizium & 13 & 9 & 36,11 & 42,86 & 78,97 & 0,2656 \\
\hline 3 & Aspergillus & 3 & 3 & 8,33 & 14,28 & 22,61 & 0,0343 \\
\hline 4 & Total & 36 & 21 & $100 \%$ & $100 \%$ & $100 \%$ & 0,6627 \\
\hline
\end{tabular}

Information:

$\mathrm{KM}=$ Absolute Density KR $=$ Relative Density Par $=$ Paribun Per $=$ Persadanta

INP = Important Value FM = Absolute Frequency Bar = Barus Julu Suk = Likes Julu

FR = Relative Frequency of Rum = House of Rih

Tabel 3. List of Frequency Distribution of Pree Test Values

\begin{tabular}{|c|c|c|c|c|c|c|}
\hline No & Interval Class & $\mathrm{fi}$ & $x i$ & $x i^{2}$ & fi.xi & fi.xi ${ }^{2}$ \\
\hline 1 & $33-41$ & 2 & 37 & 1369 & 74 & 2738 \\
\hline 2 & $42-50$ & 3 & 46 & 2116 & 138 & 6348 \\
\hline 3 & $51-59$ & 5 & 55 & 3025 & 275 & 15125 \\
\hline 4 & $60-68$ & 2 & 64 & 4096 & 128 & 8192 \\
\hline 5 & $69-77$ & 7 & 73 & 5329 & 511 & 37303 \\
\hline 6 & $\Sigma$ & 19 & 275 & 15935 & 1126 & 69706 \\
\hline
\end{tabular}

Tabel 4. List of Frequency Distribution of Post Test Values

\begin{tabular}{ccccccc}
\hline No & Interval Class & fi & xi & $x i^{2}$ & fi.xi & fi.xi \\
\hline 1 & $54-60$ & 2 & 57 & 3249 & 114 & 6498 \\
\hline 2 & $61-67$ & 1 & 64 & 4096 & 64 & 4096 \\
\hline 3 & $68-74$ & 5 & 71 & 5041 & 355 & 25205 \\
\hline 4 & $75-81$ & 7 & 78 & 6084 & 546 & 42588 \\
\hline 5 & $82-88$ & 4 & 85 & 7225 & 340 & 28900 \\
\hline 6 & $\Sigma$ & 19 & 355 & 25695 & 1419 & 107287 \\
\hline
\end{tabular}




\section{Discussion}

From the results of observations of fungal growth in larvae of Tenebrio molitor observed for 2 weeks, each soil sample showed different fungal growth. The village sample of Rumah Rih and Persadanta village are the highest village samples in which Tenebrio molitor larvae are all infected with entomopathogenic fungi, while the village of Barus julu is the village sample that has the lowest level of Tenebrio molitor larvae infected by fungi, only 4 larvae are infected with entomopathogenic fungi. From the data (Table 3) it can be seen that the highest average white fungal infection in Tenebrio molitor larvae is 2.5 larvae while the highest average of green fungal infections in Tenebrio molitor larvae is 2.5 larvae and the highest average fungal infection yellow in Tenebrio molitor larvae is 1 larvae.

Based on observations and identification of entomopathogenic fungi successfully collected from various rhizosphere samples of Brassica chinensis plants taken from 5 villages in Berastagi, there were 35 isolates. From the results of identification of entomopathogenic fungi, 3 genera were found with different macroscopic characteristics. For microscopic characteristics, it is observed the shape of conidiophores and conidia of each genus.

Following are entomopathogenic fungi data obtained from each of the 5 village samples. From the diversity results showed the difference where Beauveria fungi had the highest diversity of entomopathogenic fungi of 0.3628 and Aspergillus fungi had the lowest diversity of 0.0343 . Based on the table it can be seen that the Absolute Density (KM) of Beauveria is 20, Metarhizium 13 and Aspergillus Absolute Frequency (FM) Beauveria and Metarhizium are 9 and Aspergillus is Relative Density and the highest Relative Frequency is obtained Beauveria namely $55.56 \%$ and $42.86 \%$ while the lowest relative density and relative frequency obtained by Aspergillus species are 8.33\% and $14.28 \%$. For the Importance Value Index Beauveria has the highest index of $98.42 \%$ and Aspergillus has the lowest importance value of $22.61 \%$. Based on the table it is known that Beauveria has the highest diversity with a value of 0.3628 and Aspergillus has the lowest diversity value of 0.0343. Based on the table above it can be seen that the average value of diversity of the three fungi obtained was 0.6627.

From the calculation results, it can be seen that there are 5 classes of pre test interval values and 5 class lengths for each class. In the table it is known that $\sum$ fi.xi is 1126 so an average value $(\mathrm{x})$ pre-test $=59.26$ and standard deviation $(\mathrm{S})=12.86$. and from the results of the post test calculation it can also be seen that the highest score of students is 86 which was obtained by 3 students and the lowest value was 54 which was obtained by 1 student. the combined results can be seen the initial ability of Semester VI students before studying the Entomopathogenic Exploration Fungi material. Student grades are obtained using a scale of 10-100. The highest score obtained by students is 77 with the number of students who received the score is 2 students, while the lowest score obtained by students is 33 with the number of students who earned the score is 1 student.

\section{CONCLUSION}

From the results of the study it can be concluded that:

1. The results of entomopathogenic fungi exploration found 3 genus entomopathogenic fungi from rhizosphere soil samples of Brassica chinensis plants namely Metarhizium,

2. Beauveria, and Aspergillus which can be used as bioinsecticides. Beauveria is the most dominant entomopathogenic fungus found in each village sample compared to Metarhizium and Aspergillus.

3. The highest diversity of entomopathogenic fungi was found in Beauveria of 0.3628 , while Aspergillus had the lowest diversity of 0.0343 while the overall fungi diversity was 0.6627 based on the criteria for the index of fungi diversity that was found to have a low level of diversity.

4. Based on the pre-test results obtained an average ( $\mathrm{x}$ ) student value of 59.26 with a standard deviation (S) of 12.8 , while the post-test results obtained an average $(\mathrm{x})$ student value of 73.68 with a standard deviation 8.53. From the research data above, there is an increase in student learning outcomes in entomopathogenic fungi submateri.

\section{REFERENCES}

Alwi, Hasan et.al. (2006). Kamus Besar Bahasa Indonesia. Jakarta: Balai Pustaka

Amalia, N. (2013). Identifikasi jamur Aspergillus flavus pada kacang tanah (Arachis hypogaea L ) yang dijual di pasar kodim. Jurnal Analis Kesehatan klinikal Sains. Volume1(Nomor 1) : 1-10

BSNP. (2006). Kurikulum Tingkat Satuan Pendidikan (KTSP). Jakarta: Departemen Pendidikan Nasional.

Fibriana, Fidia \& Andin Vita Amalia. (2016). Potensi Kitchen Microbiology Untuk Meningkatkan Keterampilan Teknik Hands-On Dalam Pembelajaran Mikrobiologi. Jurnal Unnes. (Volume 5 Nomor 2): hlm 1211-1213.

Handayanto, E \& Hairah, K. (2007). Biologi Tanah.Yogyakarta: Pustaka Adipura.

Hasanuddin. (2003). Peningkatan peranan mikroorganisme dalam sistem pengendalian penyakit tumbuhan secara terpadu. http//library.usu.ac.id/download/fp/fphasanuddin.pdf. hlm 66.

Herlanti, Yanti et. al.. (2012). Literasi Mikrobiologi pada Siswa dan Mahasiswa Calon Guru Madrasah Aliah. Jurnal Proseding Seminar Nasional 
Pendidikan IPA. ISBN 978-602-17290-0-7. UIN Syarif Hidayatullah, Jakarta.

Herlinda, S., Mulyanti, S. I \& Suwandi. (2008). Jamur Entomopatogen Berformulasi Cair Sebagai Bioinsektisida Untuk Pengendali Wereng Coklat. Jurnal Agritop. (Volume 27 Nomor 3) : hlm 119-126.

Intan, Ratna Dewi A. (2007). Rhizoba Bacteria Pendukung Pertumbuhan Tanaman Plant Growth Promotor Rhizobacteria. Jatinangor: Fakultas Pertanian Universitas Padjadjaran.

Indrayani. (2011). Potensi Jamur Entomopatogen Nomurea rileyi (Farlow) Samson Untuk Pengendalian Heliciverpa armigera Hubner Pada Kapa. Balai Penelitian Tanaman Tembakau Dan Serat. Malang. hlm 11.

Mandarina, D. (2008). Uji Efektifitas Beberapa Entomopatogen Pada Larva dan Imago Brontispa longissima Gestro. (Coleoptera: Chrysomelidae) di Laboratorium Fakultas Pertanian, Universitas Sumatera Utara. Jurnal Pertanian. (Volume VII Nomor 1). hlm 63.

Novizan. (2002). Membuat dan Memanfaatkan Pestisida Ramah Lingkungan. Jakarta: AgroMedia.

Noverita, (2009). Identifikasi Kapang dan Khamir penyebab penyakit manusia pada sumber Air minum penduduk pada sungai Ciliwung dan sumber air sekitarnya. Jurnal Vis Vitalis. Volume 2 (Nomor 2): 12-22.

Nugraha, I., Kusumawardhani, G.\& Fitriani. (2010). Potensi Cendawan Entomopatogen di Indonesia. Program krearivitas mahasiswa. Bogor: Fakultas Pertanian, Institut Pertanian Bogor.

Nurudin, Febrian Achamd et. al., (2013). Keanekaragaman Jenis Ikan Di Sungai Sekonye Taman Nasional Tanjung Puting Kalimantan Tengah. Jurnal Unnes. (Volume 2 Nomor 2): hlm 3.

Prayogo, Y. (2006). Upaya Mempertahankan Keefektifan Cendawan Entomopatogen untuk Mengendalikan Hama Tanaman. Jurnal Litbang Pertanian. Volume 25 Nomor 2. hlm 47-54. Balai Penelitian Kacangkacangan dan Umbi-umbian, Malang.

Purnomo, Hari. (2010). Pengantar Pengendalian Hayati. Yogyakarta: ANDI.

Rabiah Al Adawiah, Putri. (2016). Isolasi Dan Identifikasi Cendawan Indigenous Rhizosfer Tanaman Kentang (Solanum Tuberosum L.) Di Buluballea Kelurahan Pattappang Kecamatan Tinggimoncong Kabupaten Gowa. Jurnal Pertanian. (Volume 5 Nomor 16) : hlm 1-65

Rukmana, Rahmat. (1994). Bertanam Petsai \& Sawi. Yogyakarta: Kanisius.

Safika, Jamin, P., dan Aisyah, S. (2014). Deteksi Aflatoksin B1 pada jenis makanan olahan jagung menggunakan Enzyme Linked Immunosorbent Assay (ELISA). Jurnal Medika Veterinaria. 9 (1): 23-25
Sastrahidayat, I.R. (1990). Ilmu Penyakit Tumbuhan. Surabaya: Usaha Nasional.

Sudarmo, Subiyakto. (1991). Pestisida. Yogyakarta: Kanisius.

Sudjoko. (2001). Membantu Siswa Belajar IPA. Yogyakarta: FMIPA UNY.

Sugiyono. (2016). Statistika untuk Penelitian. Bandung: Alfabeta.

Suhardi. (2007). Pengembangan Sumber Belajar Biologi. Yogyakarta : Jurdik Biologi FMIPA UNY.

Sulistyowati E., Rahayu DS \& Aini FN. (2012). Aplikasi Jamur Paecilomyces lillacinus untuk Menginduksi Ketahanan Tanaman Kopi terhadap Nematoda Parasit, Pratylenchus coffeae. Di dalam : Efektivitas Jamur Paecilomyces lillacinus Strain 251 terhadap Nematoda Parasit, Pratylenchus coffeae. Prosiding Insinas, 29 - 30 November. Pusat Penelitian Kopi \& Kakao, Indonesia.

Sunarto T., Djaja L \& Meliansyah R. (2009). Pengendalian biologi nematode Meloidogyne spp. dengan jamur Paecilomyces fumosooroseus dan bakteri Pasteuria penetrans serta pengaruhnya terhadap tanaman buncis (Phaseolus vulgaris L). Jurnal Ilmu-Ilmu Hayati dan Fisik. Bandung. Volume 11 Nomor 1: hlm 217-219.

Syafurrisal, A. (2014). Pengaruh Penyimpanan Pakan Udang Komersial Dengan Penambahan Volume Air Berbeda Terhadap Pertumbuhan Jamur Dan Kandungan Protein Kasar. Universitas Airlangg, Surabaya. Jurnal Perikanan dan Kelautan. (Volume 4 Nomor 10): hlm 40.

Trizelia et.al. (2015). Keanekaragaman cendawan entomopatogen pada rizosfer berbagai tanaman sayuran. Jurnal Pertanian. (Volume 1 Nomor5): hlm 1-7.

Wahyudi. (2008). Jamur patogen serangga sebagai bahan baku insektisida. pemanfaatan mikroba dan parasitoid dalam agroindustri tanaman rempah dan obat. Jurnal Perkembangan teknologi tanaman rempah dan obat. (Volume 12 Nomor 21). hlm 28.

Widiyanti, Ni Luh P.M. dan Muyadihardja, S. (2004). Uji Toksisitas Metarhizium anisopliae Terhadap Larva Nyamuk Aedes Aegypti. Media Litbang Kesehatan Volume XIV Nomor 3.

Yanti, Itat. (2013). Pengaruh Jamur Entomopatogen Metarhizium anisopliae Terhadap Mortalitas Serangga Penyerbuk Trigona sp.. UIN Sunan Gunung Djati.. Jurnal Pertanian. (Volume 7 Nomor 13): hlm. 25.

Yulipriyanto, Hieronymus. (2010). Biologi Tanah dan Strategi pengelolaannya. Yogyakarta: Graha Ilmu. 